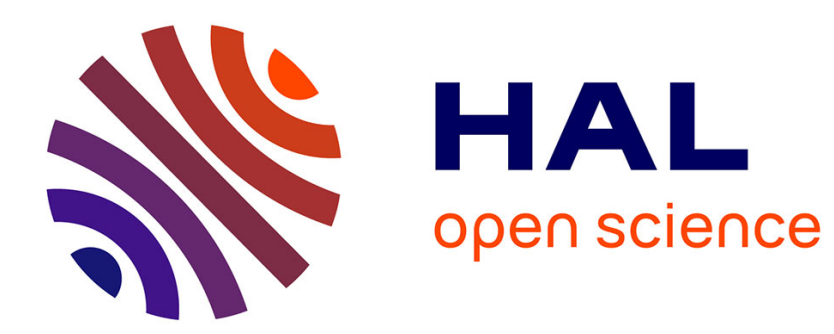

\title{
Is Trust an Epistemological Notion?
}

Gloria Origgi

\section{To cite this version:}

Gloria Origgi. Is Trust an Epistemological Notion?. Episteme, 2004, 1 (1), pp.61-72. ijn_00000653

\section{HAL Id: ijn_00000653 \\ https://hal.science/ijn_00000653}

Submitted on 5 Dec 2005

HAL is a multi-disciplinary open access archive for the deposit and dissemination of scientific research documents, whether they are published or not. The documents may come from teaching and research institutions in France or abroad, or from public or private research centers.
L'archive ouverte pluridisciplinaire HAL, est destinée au dépôt et à la diffusion de documents scientifiques de niveau recherche, publiés ou non, émanant des établissements d'enseignement et de recherche français ou étrangers, des laboratoires publics ou privés. 


\section{GLORIA ORIGGI}

Is Trust an Epistemological Notion?

Knowledge is a collective good. Only a small part of our knowledge of the world is
generated by our own personal experience. Relying on what others say is one of the most fundamental ways to acquire knowledge, no only about the exlemal world, but also abou where we were bon. To use Mary Douglas' words: "Our colonistion of each o ders' ginds is the price we pay for thought". Traditionally, epistemology had banned from genuine knowledge beliets acquired by trusting opposed to opinion, should ultimately be based on individually held clear and distinct ideas (Descartes) or sense impressions llockel together with sound relations among these ideas. An individualistic stance has persisted in the contemporary debate, claiming tha individually held reasons and individual cognitive states are the only ground of justification of our beliefs.

such as heloss a number of social phenomena such as the role of expertise in public decisions within democratic sociefies, collaborative work in "Big Science and in the Academe, or the informational explosion due to new media and technologies have forced af least a part of contemporary epistemology to incorporate and authory. A divion of cognitive labour is now recognized as a property of every colvit system, science included. ${ }^{2}$

Although there is widespread agreement that our epistemic dependence on ofer our epistemic dependence on other people's
knowledge is a key ingredient of our cognitive life, the role of trust in this dependence is much more open to debate. Is trust in epistemic authority-or "epistemic frust" for short-an epistemological notion in any sense, or is simply a bridge-concept that connects ou epistemological concerns to moral issues?
Should we depict it in terms of the more familiar sociological notion of trust as a basis for cooperation? If epistemic trust and moral or social frust are different hings, are they related, and how? "I is obvious enough that people's what rules and principles govern the distribution of knowledge in society, who are the experts, why they should be believed-influences their trust in its social order and it is influenced by it? Good illustration of this was provided by recen events involving governments' invocation of events involving governments invocation of
Intelligence expert's dossiers on the alleged existence of weapons of mass destruction in Iraq to justify war, and the backlash of public opinion when this expertise proved unreliable and its political exploitation disingenuous. Still, while the existence of strong relations between moral/social and epistemic/cognifive notions of trust is not in doubt, their character has no been clearly elucidared.

To contribute to such an elucidation, I will review different approaches to epistemic authority, some that come from outside of philosophical epistemology, and others at epistemological approaches, I will pay particular atention to the tension between reductionist vs, non-reductionist approaches to trust and testimonial knowledge. Unovoidably the accounts I will give and the contrasts | will draw will be oversimplified. Still, I hope they will suffice to give plausibility to the first main claim of this article, namely that epistemic trust is illuminated by all these diverse approaches and fully accounted for by none of them, because if genuinely involves a variety of cognifive and social mechanisms that can be normatively evaluated from several points of view. I will then present what I believe is a neglected and poorly understood form of 
verbal comprehension. This pragmatic form of epistemic trust calls, I will argue, for a nonreductionist account. Therefore-and this will
be my second main claim-in no domain be my second main claim-in no domain where social knowledge relies on verbal communicalion can epistemic trust

\section{Non-epistemological approaches}

Epistemic authority and trust are not just philosophical topics, they are important aspects indeed should be studied as social historical phenomena To give iust one example, in his influential book A Social History of Truth, Steven Shapin (1994) reconstructs the role of Sentlemanly culture in determining credibility in the scientific practices of early modern science, in particular in the constitution of the British Royal Academy and its new experimental standards for scientific discourse. Trust and civility are inseparable concepts: they define a cultural system, that is, a set of presuppositions that guides "conversation" not just in its ordinary sense but also in the Latin sense of conversatio, that is, the art of conducting oneself in social interactions. In this cultural system, an honourable gentleman is precisely one who deserves to bentruled. Social practices of recognition, cultural heuristics and epistemic constitution of any body of knowledge, science included Shapin's history of trust has the merit of embedding deference to epistemic athority in historical and practical contexts, in contrast to more abstract and formalized approaches found in philosophy. His approach converges in this respect with sociological research land in particular sociology of science) $\left.\right|^{4}$ and, for that matter, sociological commonsense. In people's ordinary deference to the epistemic authority of others, epistemological, moral and cultural reasons are completely intertwined. The ethnomethodologist Harold Garfinkel nicely illustrated the difficulty of disentangling moral and cognitive trust when he suggested the following informal experiment: try to everyday foctual reports; she will find it an intolerable attack on her person and her moral
integrity, and it will be hard to re-establish the elationship even after having been told of your Does the

Does the sociological or historical perspective show that trust or authority are just historically situated social constructions that cacial-historical context? Does it or their melevant philosophical issues regarding the hature and rationality of trust? It is of course quite possible to acknowledge the fruiftuness of the social-scientific approach without embracing the kind of relativism that is frequently associated with it.

From within philosophy itself, trust in epistemic authority is being approached from a variety of perspective, and not just from a strichly epistemological one. Affer all, trust seems to be a crucial aspect of interpersonal relationships, of the social and political order, and of cooperation in general. Trust is seen as something that is there and calls for a definition. This is not to say that there is In portical philosophy trust is standardy seen as a volphtary transfer of powe to those who govern, a transfer that cannot be justified simply in terms of coercion or of rational argument ${ }^{6}$ In social theory, trust is frequently treated as a form of rational choice to pursue ongoing cooperation.? In moral philosophy, trust is often considered as a social virtue that cannot be reduced to strategic thinking. ${ }^{8}$ All these elusive idea of an intentional surrender of control on one's own actions and decisions that seems difficult to reconcile with the autonomy of a rational agent. To what extent are these various approaches to trust in general relevant of study of hust in epistemic authorily? I have no general answer to propose to this question, possible contributions, from political philosophy rom social theory, and from moral philosophy. let me first, however, express a following cautionary remark An uncritical following approaches to moral and social trust and authority into epistemology has failed to sharpen the notions of epistemic trust and knowledge were that found in the community of authority and may have indeed contributed to birdwatchers. Among birdwatchers, reports their vagueness. "Trust" is sometimes being used such as: "A count of 32 Mediterranean Gulls with reference to the cooperation needed was made on the Isle of Wight on the 7th" are within the scientific enterprise, at other times believed withou any furner check, thanks to the with reference to the testimonial source of most strong mutual respect and sense of cooperation

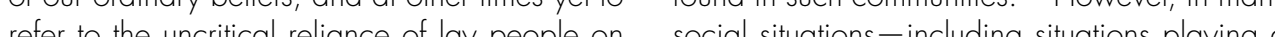
experts. Are we talking of the same thing in all major role in cultural transmission-the three cases, or should we, to begin with, information exchanged is much less acknowledge that there are many sub-varieties straightforward and raises problems not of epistemic trust iust as there are many varieties just of believability but also of comprehension. of trust in general, casting doubt on the The interplay between believability and possibility of a single integrated account? If we comprehension and the role of cooperation no entertain the possibility that we may be talking, just in epistemic but also in interpretive guidance under the name of trust, about a variety of are, I suggest, important aspects of epistemic related but different attitudes, and if we adopt, trus at least for the time being, an aim more modest than that of a developing a general theory of trust, we may be better placed to take advantage of a variely of perspectives.

Political philosophy is a source of insight for social epistemology. In political philosophy, trus is seen as a key component of the authorily relation, in which a person desists from asked to do or to believe as a condition of her doing or believing 9 Something of this kind seems at play when the lay person blindly defers to a recognised authority, be it an expert a "wise man" (or woman) or a religious leader. We are all familiar with such cases of blind deference. They typically involve the acceptance of beliefs that are only partially understood. I believe my doctor who tells me that my level of cholesterol is too high and I follow her prescription, even if my understanding of what cholesterol is is quite poor, and my comprehension of its physiological role is hopelessly metaphorical. Is this sort of deference ever justified in some relevant sense, and should epistemology pay altenion to me limink in should. which are peffecty clea but for which we lack direct evidence has contributed to giving an unrealistic picture of our dependening an socially distributed knowledge, It is as if the paradigmatic case of social transfer of irust.

Social theory approaches to cooperation drawing on rational choice and on game cheory are another source of insight for socia coral, it raises the question of what causes might often be beter served by defecing

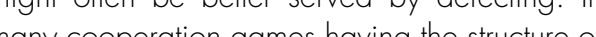
an iterated prisoner's dilemm it has been shown't2 that a tit for tat strategy of one party makes defection less advantageous than cooperation for the other party (with generalisation to the many players case). In an article entitled "Epistemological Tit of Tat," Michel Blais has argued that such a gameheorefic approach might be extended to trust Whin a scientific community. Scientists have an interest in reporting genuine observations and resulls, because the costs of uncooperative behaviour (i.e. chealing) is high, and typically consists in the public and permanent exclusion

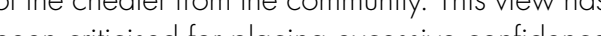
in the reliced for placing excessive confidence possible line of criticism is traints. Another adequatess of the ism is to question the Dilemma to the case of science. Som phing like a tit for tot strategy may be at work in the decision of scientific teams working on the same issues to share or not to share resuts same publication: you don't share with me, I don't epistemology. Communication is a form of cooperal it As in the case of cooperation in 
share with you. But this form of cooperation is of limited epistemic relevance. In the more epistemically significant case of the publication
of observations and results, the response to the of observations and results, the response to the production of fake evidence is not symmetrical.
It is not to produce false results in return until defectors fall back in line, it is to ostracize them. This response is not only qualitatively but also
The quantitafively asymmetrical, and costly not jus large. Why deprive the community forever from the input of competent scientists that have typically, been carried away by their theoretical convictions, rather than punish them in proportion to the damage done and then reintegrate them? Would not this be costly enough to the perpetrators to deter scientists tempted to fake their data? Ostracism of evidence-takers seems guided, at least in pant, by a sense of moral disgust among scientists who are eager to preserve their collective self-esteem and not just the epistemic value of heir output.

While a game theoretical approach may provide partial insight in accounting for trust in scientific practice, its relevance to the communication is dubious. In particular a lit for at strategy makes sense if basically the same game with similar pay-offs is played again and again and if in this game defection is advantageous unless it is sanctioned. In personal relationships, however, the goals of communication are extremely varied. Most of these goals-coordination of action for instance-are better achieved through competent and honest communication. Given this, there is no systematic and obvious way of sanctioning someone who has, on a particular occasion, pursued his advantage by means of dishonest communication. Typical reactions are Tust of a moral than of a stralegic character. rust seems to be allocaled in a manner that is coo context-sensive and too morally and psychologicaly inch Moral philosophy is a

Moral philosophy is a third source of insight is not the fact that one, after calculating the

odds, feels no risk: It is feeling no risk without calculating the odds". "In moral philosophy, rust is often analysed as a particular prior commitment to a relationship and not an outcome of the cooperafive behaviour between e pavies This prior comminent is nof basin from my interaction. Routher he fact that trust them gives me an expectation to gain from interacting with them in some occasions. According to Annette Bayer, trust and distrust re feeling responses, not cognitive states, to how we take our situation to be: an accepted vulnerability to another's possible, but not expected, ill will. To what extent is such a view of trust of interest to epistemology? Does it help capture the fundamental role of trust in the acquisition of vicarious knowledge? Epistemic ust is flust, on the one hand, in the goodwill of others, and, on the other hand, in their competence. The moral notion of trust is of clear elevance to assessing goodwill, in particular in enduring personal relationships, but it seems of Trusting the other park's willingness to take int Tccount my ow interst, ither for he sale of ouf future relation, or simply out of an affective atritude doesn't assure me that what $\mid \mathrm{am}$ obtaining is valuable information. The mord attitude of trust may yet influence the sharing of information in other ways. On the one hand it may cause interlocutors to do their epistemic best. On the other hand, it may cause the morally trusting receiver of information to display stance of epistemic trust for the sake of the elationship. She may then either lower her epistemic criteria for accepting a belief (my wiend says he is too lired to go to the cinema, would not have thought so, but I will believe heck remain inwardly sceptical and possibly . enduring personal relationships en in strong does not reduce to moral trust. Moreover, the

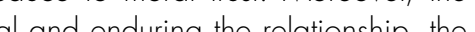
more limited is the relevance of the moral notion Int to the epistemic notion

e briefly examined arious non-epistemological approaches to trust, and argued that while they all had something to contribute to our understanding of the notion none provided
turn to epistemolog turn to epistemological approaches.

\section{Epistemological approaches}

If I grant you epistemic authority because of independent reasons - which may be direct of indirect, moral or epistemic-l have to think tha you are a reliable source of information, then if I suspend my reasons in granting you authority and I am willing to accept whatever you say iust because you believe it, then I'm granting you fundamental authority. ${ }^{18}$ This distinction between derivative and fundamenta authority retraces in part the classical distinction in the philosophy of testimony between reductionists and anti-reductionists. Hume is the historical representative of the reductionist position: According to him, reliance on testimony is based on the same kind of inductive inference that justifies any other belief, that is, on the evidence of accustomed conformity of testimonies to facls. We rely on oliners because experience has shown them to be reliable, thus we have independent reasons to believe them The non-reductionist view is historically represented by Thomas Reid, who considered category of evidence neither reducible to oher forms of perceptual or inferential evidence nor iustifiable in terms of them. As he famously wrote: "The wise and beneficent Author nature, who intended that we should be social creatures, and that we should receive the greatest and most important part of our knowledge by the information of others, hath, for these purposes implanted in our natures two principles that tally with each other. The first of these principles is a propensity to speak truth. [the second] is a disposition to confide in the veracity of others, and to believe what they tell Both reductionist and non-reductionist views of trust have developed in recent epistemology "n his 1" epistemologists that they should acknowledge
Irust as "the ultimate foundation for much of ou knowledge". This didn't imply, according to him, a major departure from usual epistemological concerns. According to Hardwig trusting others is normatively accountable in terms of a particular class of nowledge through testimony: If A has reasons to believe that $B$ has reasons to believe tha $p$. then $A$ has reasons to believe that $p$, even if the nature of $A^{\prime}$ 's reasons is irreducibly different from that of $B^{\prime}$ 's. A's reasons to believe that $p$ are based in her assessment of the "epistemic character" of B and in particular of his honesty and competence, whereas B's reasons to believe that $p$ depend on his assessment of the evidence for or against $p .{ }^{21}$ Trust is thus a matter of assessing the moral and epistemic reliability of other people on a particular subject matter. Notice that, in this account, epistemology doesn't reduce to ethics, nor the other way around. Rather, what is claimed is that epistemology should inlegrale some moral standards. Tust inelt reduces to a r epistemic and moral reasons.

Goldman and Philip Kitcher in particular ${ }^{22}$ develop a reductionist account of particular," considerations of social factors contribute to reasons and justifications for holding beliefs. They integrate the kind of reasoning that iustifies our trust in vicarious knowledge in an overall view of cognition that may be described as rationalist. In this perspective, trusting others le criteria to assess their compelence and trustworthiness. Fine Perlions can be made among these criteria. People may have different reasons to allocate authority to others, all equally rational. A person may allocale contextual authority to people she position to provide bome in a better epistemic such a case, trusting others is a way In exploiting their perception and reasong of proxy for one's own. We use experts as "tools" ${ }^{\text {"23 }}$, as we use a telescope to enhance our perception. Understanding a social process of development and distribution of knowledge may give me indirect criteria for trusting specific 
sources. I may have a good understanding of the process of assessing and filtering information in peer reviewed journals and
evidence about the quality of this process in evidence about the quality of this process in different journal. This provides me reasons to put
greater or lesser trust in the article published in track records on a paricular issued with you that you have eared authority and judge reputation on this issue ${ }^{24}$ The anclysis of such fine-grained criteria for the allocation of trust contributes to a better epistemological description and evaluation of various systems of distribution of knowledge land also to the design of such systems

It would be hard to dispute lexcept from a radical sceptic point of view) that we often have reasons to firust others on specific subject matters and that many of our beliets are acquired through such reasoned trust, and justifiably so. But are vicarious beliets generally based on such reasoned trust? And when they are not, can they nevertheless be justified? It is quite debatable whether it is ever rational to accep what another person says on the simple basis authority is similar to the acceptance of political authority as standardly conceived, in that i involves a form of "surrender of iudgement."

The difference between derived and fundamental authority land the associated reductive and non-reductive notion of trust) is no that one is justified and the other not, it is tha people who trust derived authority attend to reasons to do so in each case, whereas people who trust fundamental authority do so withou attending to reasons. Proponents of the notion of fundamental authority and of a non-reductive account of trust, on the other hand, provide justifications for such authority and such trust. Reid's justification appeals to the wisdom and beneficence of the "Author of nature." A standard move in contemporary epistemology it as an extension of the necessary selftust ha we ar ant to our past, present and fut wudgements. Granting no authority to ourselves would amount to a form of hyperscepticism about the very possibility of holding iustified beliefs. But if we take our

EPISTEME June 2004 as proxy for present ones on no other grounds con the fact that they are our judgements, couldn' we accepl other people's judgements so she so egoist,

Moreover, as Gibbard has argued, other peoples influence has been pervasive in our pat our norms of reasoning today have been influenced by others, we cannot but accord egitimacy to this influence and should not exclude the legitimacy of possible influence of
entimacy to this influence and shold not his kind in the future. Thus, he argues, we must accord others some fundamental authority.".25

How good is the analogy between the authority we grant our own cognitive mechanisms and the authority we grant others? Both our cognitive mechanisms and other people can-and often do-misinform us. So we may be justitied in relying on these two source of hirmalion if, or when, we have no betier choice, but we are not justified in granting hem absolve authority. So far the analogy holds. Our own cognilive mechanisms malfunctioning, but otherwise, their function is to inform us: they are working for our own good so to speak. When others misinform us, it may be that they are themselves mistaken and cognitively malfunctioning, or it may be that they are serving their interest at the expense of ours. Here the analogy breaks down: there are specific reasons, having to do with possible divergence of interests, to mistrust others, easons that do not apply to oneself. On the other hand, there is much more accumulated knowledge and competence in our social surroundings than inside us. There are therefore specific reasons to seek from others information hat could not be found in oneself, or only less eliably. The analogy breaks down a second by Ruth, Millikan 26 mainfained, for instance form of cognition by proxy, and hat we ar as predisposed to paxy, and hal we are as information as information from our senses. To see whether this is indeed the case, we must see Whether this is indeed the case, we must
turn to the mechanisms of verbal communication, which should be the first place to look when looking for fundamental

If trusting others is as fundamental a channe through which we acquire information as are perception or memory, this should be reflected
in the functioning of linguistic communication yust as it is in the mechanisms of percepilion and semantics analysed by Hilary Putnam and Tyer Burge, In his famous 1975 article, "The Meaning of Meaning", Putnam pointed out tha the use of language is intrinsically deferential. do not need to be an expert chemist to use the word "aluminium"-even if I am not able to distinguish aluminium from steel-because the "distribution of linguistic labour" as Putnam calls it, links my use of this term to the relevan knowledge possessed by the metal experts in my linguistic community. Deference to "expert" is particularly manifest in language acquisition. A child may hear the word "bat" and start using I with little or no understanding of what bats are while still intending to refer to what adults around her would refer to in using the term and tacitly deferring to their authority

should be distinguished from and reference epistemic attitude of acceptance of statements. Still, viewing linguistic practices as intrinsically deferential at a semantic level goes well with seeing them as deferential at an epistemic level. It is no surprise, therefore, to see Tylor Burge argue that relying on interlocution is so fundamental that we are entitled to "accept as true something that is presented as true and that is intelligible [to us] unless there are stronger reasons not to do so (what he calls the Acceptance Principle). Note that we do not use this principle as a justification according to Burge: we re simply entifited to acquire information according to the principle" In his book Testimony, Anthony Coady exploits the Davidsonian Pinciple of Charity to denve an a prioni jusiticalion of lesimony bution of truths to our interlocutors Speaking the truth and sharing public meanings are so closely intertwined that the very existence of public language would be impossible without strong positive correlation between the sentences uttered in that language and the facts hey represent. Even reductionist approaches to lestimony presuppose the existence of a public language, and therefore of at least some a priori positive correlation between testimonies there would be no language in the first place. Burge and Coady base an a priori justification of trust in testimony on fundamenta properties of language use, although differen ones. For Burge it is what he sees as the purely preservative character of successful linguistic communication that entitles us to rely on what we understand other to be saying. Just as memory, he argues, understanding an utterance preserves without any addition or transformation the content of the thought communicated, and his is what makes it unproblematically acceptable. For Coady the relevant property is and the vossibility of a common language poses a gere of mulual understanding presup idea that comprithul use of speech. Burge's been questioned by Anne Bezuidenhout ${ }^{28}$ A totally ignos enpical accounts of the pocess of comprehension: making sense of what other people say is an inferential interpretive process and not a mere decoding one. I will return to this point in the final section. Here I canno discuss in detail Coady's insightful position. Le me just mention one possible objection. What is needed for the stabilisation of shared meanings, in his Davidsonian perspective, is a mass of true and trivial statements, as is indeed found in ordinary communication. However, what an individual is told, and in particular the non-trivial stanementis she particularly cares about, is not a should sample of all statements. How then should the lact that, on average, most statements are true (and trivial) justify an examination of what she ir trut and withou interlocutors on specific topics?

A finegrained analysis of what is at stake in a better understanding of trust in needed for acquisition. Many of the tensions that shape the debate on trust in epistemology might be 
attenuated, I believe, by looking at the very cooperafive speaker will abide by the maxims

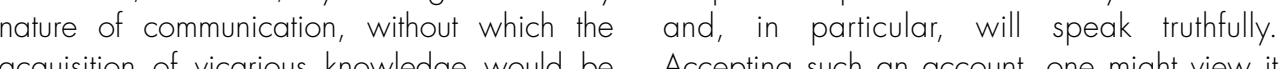
impossible.

\section{The pragmatics of trust}

While epistemology has taken an interest in the empirical study of cognition, and social epistemology in the empirical study of knowledge institutions, very little attention has
been paid to the empirical study of communication, even by those who, like Burge or Coady, give a central place to the nature of communication in their account of naistemic trust. The transfer of testimonial information is typically viewed as being achieved by means of a linguistic encoding by the speaker of her meaning and a decoding of that meaning by
her audience. In fact, hardly anybody involved in the empirical study of comprehension accepts this "code model" of linguistic communication. Modern pragmatics, inspired by the work of the philosopher Paul Grice, ${ }^{29}$ takes for granted that comprehension is largely inferential. As argued by Sperber and Wilson (1995), a linguistic utterance is best viewed not as an encoding of the speaker's meaning, but as a this meaning can be inferred. The result of his meaning can be infered. The result of linguistic decoding is typically an ambiguous and gappy concepis stuctur. Ihat vastly is based on this decoded conceptual structure taken together with contextual information and guided by maxims of conversation laccording to Gricel or by expectations of relevance raised by the utterance itself laccording to Sperber \& Wilson). ${ }^{30}$

According to Grice, successful communication involves cooperation among interlocutors. Their conversation must have a common goal for at least a common direction), and their ulerances must be contributions to this common goal. Interlocutors should conform to maxims of conversation that guide their cooperation. Among these, there are maxims regarding ruinfulness, and in paricular he maxim "Do not

say what you believe to be false, which Grice trust in the relevance of the speaker in order to understand her. When truthfulness is a condition for relevance, as it often is, hearers adopt stance of frust in the speaker's truthuluness too. To give just one illustration, consider the following

Watchmaker to Mary: It will take some time to repair your watch

Literally understood, the watchmaker's statemen is a truism since repairing a watch is a process exlended over time. If Mary was interpreting th utterance just on the basis of a presumption of truthufuness or of a Davidsonian principle of charily, she might be satisfied with its literal truistic meaning. Looking for an interpretation understands that repairing her watch will take more time than she might have expected. For instance, if she might have expected the watch to be repaired the next day, she will understand the watchmaker as meaning that it will take several days. Why not understand him to mean that it will take an absurdly high amount of time, years for instance, since this would be even more relevant? It would be relevant only if true, otherwise it would be just a poor joke. Here relevance implies truth. Mary takes the watchmaker to be committing himself not to the truth of any interpretation of "some time" in his unterance, but to the livun of the first interprefation that is relevant enough to be worth her attention. Having understood what the warchmaker means, she may then choose to question its in relevance, which involved a stance of trust truthfuness as a subpart, in order to understond what her intelocutor meant.

Ifferent pragmatic approaschess the merits of Grice and that of Sperber and Wilson. Whatever their differences, they converge in suggesting that a stance of trust that may be directly trust in truthfulness, or that may be trust in relevance which typically implies truthfulness) is an automatic part of the interpretation process. In engaging in conversation, and through this stance of trust, people develop a environment". ${ }^{33}$ They do so at least tentatively in the context, and for the sake of the verbal exchange and of social intercourse more generally. This may ready them for a full-fledged acceptance of the contents of this common ground, but this is nol automatic. The stance of frust involved in communication is both withdrawn when it comes to accepting be content understood. Such an appreach the fore meets the anti-reductionist requirement of "non gullibility": that is, the requirement that people should not automatically accep whatever their interlocutors say.

In young children, the stance of trust needed for comprehension may extend into quasiaulomalic acceptance. This may be a distinctive fin of a phase of cognifive development where language acquistition, language understanding and the acquisition of information about the world are wholly intertwined processes. ${ }^{34}$ Once, however, children master to a sufficient level the lefined spoken in their community and have display a somernhat me abilities, they may oward anformation that comes from others. This doesn't mean hat hey systm alically. This checking the truth or the probability of what hey are told. Rather, what they become better at is checking the intentions of their interlocutors and the reasons they have to communicate with them. Thus they may start developing more fine grained heuristics for assessing credibility and A vorthiness.

A large part of our knowledge reaches us through copm much more creative and richly inferpretive process than is usually acknowledged. We do not fust accept information, but we reconstruct in a manner relevant for us. Trusting other people is involved in the constructive process of under is no blind truts in passive "blind trust". There sense as there are nunication in ine same perception. A stance of Irust, howeve, is par of the interpretive competence that gronds our capacities to understand, to tean how to communicote, and to cope with the complex social networks of knowledge that make us humans. 


\section{References}

Adler, J. (1994) "Testimony Trust, Knowing" Journal of Philosophy, 94, pp. 264-265. Baier, A. (1986) "Trust and Antitrust" Ethics, 96, pp. 23 1-260.

Bezuidenhout, A. (1998) "Is Verbal Communication a Purely Preservative Process?" The Philosophical Review, 107, pp. 261-288.

(Bloom, P. (2000) How Children Lean he Meaning of Words, MiT Press. Burge, T. (1993) "Content Preservation The Philosophical Review, 102, pp. 457-487. Coady, A. (1992) Testimony, Clarendon Press, Oxtord.

Foley, R. (1994) "Egoism in Epistemology" in F. Schmitt (ed.) Socializing Epistemology,

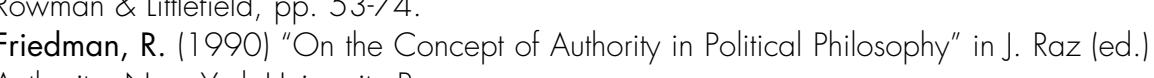
Authority, New York University Press.

Fuler, S. (1988/2002/ Social Epistemology, Indiana University Press.

Gambefta, D. (1967) Sus, Cambidige University Press.

(1)

Goldman, A. (2000) "Social Epistemology" in Stanford Encyclopedia of Philosophy,

hitp://plato. stanford. edu/entries/epistemology-social//

Grice, P. (1989) Studies in the Way of Words, Harvard University Press.

Hertzberg, L. (1988) "On the Atitude of Trust" Inquiry, 31; 307-322.

Holton, R. (1994) "Deciding to Trust, Coming to Believe" Australasian Journal of Philosophy,

72, pp. 63-76.

Kitcher, P. (1992) "Authority, Deference and the Role of Individual Reasoning in Science"

in McMullin (ed.) The Social Dimension of Science, Notre Dame University Press.

Kitcher, P. (1993) The Advancement of Science, Oxford UP.

Kitcher, P. (2001) Science, Truth and Democracy, Oxtord University Press.

Lagerspetz, O. (1998) Trust. The Tacit Demand, Kluwer.

Moran, R. (lorthcoming) "Believing the speaker" manuscripl.

Origgi, G. (2000) "Croire sans comprendre Cahiers de Philosophie de l'universté de Caen

Origgi, G. (2004) "Croyance, dééérence et témoignage" in E. Pacherie, J. Proust leds.

hilosophie Cognitive, Presses de la Maison des Sciences de l'Homme, Paris

Origgi, G., Sperber, D. (2000) Evolution, Communication and the Proper Function of Language"

Pouivet, R. (2003) Qu'estce que croire? Vrin, Paris.

Putnam, H. (1975) "The Meaning of "Meaning"" in K. Gunderson (ed.) Language, Mind and

Reality, University of Minnesota Press, pp. 131-193.

Shapin, S. (1994) A Social History of Truth, Chicago University Press.

Sperber, D. (2001) "An Evolutionary Perspective on Testimony and Argumentation"

Philosophical Topics, 29, pp. 401-413

Sperber, D., Wilson, D. (1986/1995) Relevance: Communication and Cognition,

Basil Blackwell.

Williams, B. (2002) Truth and Truthuluness, Princeton University Press.

Wilson, D., Sperber, D. (2002) "Truthfulness and Relevance" Mind, 11 1, n. 443, pp. 583-632.

\section{Notes}

M. Douglas (1975) Implicit Meanings, Routledge and Kegan Paul.

"The idea of a "division of cognitive labour" is due to Philip Kitcher. Cf. Kitcher [1993: ch.8] The mutual dependence of trust in cognitive and social order has been especially stressed by Steven Shapin : "It is not the case that the moral order fails and then the cognitive order fails, or the reverse. They fail together, just as they stabilize together." Cf. Shapin [1994:35].

See for example Bruno Latour $11987 /$ Science in Action: How to follow scientists and engineers through society, Harvard University Press.

${ }^{5}$ Cf. H. Garfinkel (1967) Studies in Ethnomethodology, Prentice Hall.

"CF. R. B. Friedmann (1973) "On the Concept of Authority in Political Philosophy", in R.E. Flatham (ed.) Concepts in Social and Political Philosophy, McMillian, London. See for example R. Hardin (2002) Trust and Trustworthiness, Russell Sage Foundation; D. Gambetta (1988) Trust: The Making and Breaking of Co-operative Relations, Basil Blackwel. Paris, pp. 283288 .

9 For this definition of the authority relation, cf. R. Friedman [1973], p. 77.
${ }^{10}$ Partially understood beliefs have been particularly investigated by Dan Sperber. Cf. D. Sperber [1982] "Apparent Irrational Beliefs", in M. Hollis \& S. Lukes leds R Rationality and Relativism, Basil Blackwell, pp. 149-180; [1997] "Intulitive and Reflective Beliefs", Mind \& Language, 12, pp.67-83. Cf. also G. Origgi (2000) "Croire sans comprendre", Cahiers de Philosophie de l'Université de Caen, 34, pp. 191-202

"I owe the example to Dan Sperber. The particular report quoted was taken from the web site of the British Trust for Ornitology (www.bto.org). The list of reports was dated April $8^{\text {th }} 2004$. C. R. Axelrod (1984) The Evolution of Cooperation, New York, Basic Books. Cf. M. Blais (1987) "Epistemic Tit for Tat", Journal of Philosophy, 84, 7, pp. 363-75 Cf. J. Hardwig (1991) "The Role of Trust in Knowledge" Journal of Philosophy, 87, n. 12, pp. $693-708$

Fis an account of the asymmetry between games involved in communication and iterated Prisoner's Dilemma games, see Sperber (2001) "An Evolutionary Perspective on Testimony and Argumentalion",

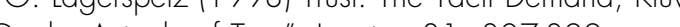

17 For the nod of "siace of

Holton (1994) "Deciding to Trust, Coming to

. 63-76, although he employs it in a quite dif-

ferent way.

${ }^{18}$ On the notion of fundamental authority see A. Gibbard (1990) Wise Choices, Apt Feelings, Harvard University Press, R. Foley (1994) "Egoism in Epistemology", in F. Schmitt (ed I)

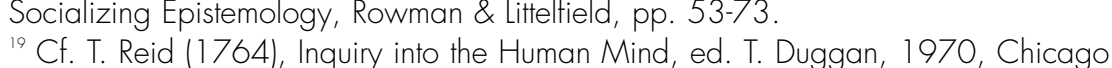
${ }^{20} \mathrm{Cf}$. J. Hardwig [1991], p. 694

Hardwig had already stated his Principle of Testimony in a previous paper: Cf. J. Hardwig (1985) "Epistemic Dependence", 82, 7, pp. 335-49. For a criticism of his principle, see F. Schmitt (1988) "On the Road to Social Epistemic Interdependence", Social Epistemology,

2.4, pp. 297-307. 
22 I gather in this perspective such different approaches as that of Philip Kitcher [1993; 1994] and Alvin Goldman [1999]. For a detailed analysis of these different positions, see A. Goldman, this volume.

(1996) The Elm and the Expert, MIT Press,

The concept of "earned authority" is analysed in Kitcher [1992].

${ }^{25}$ Cf. A. Gibbard, cit, p. 180.

${ }^{26} \mathrm{Cf}$. R. Millikan (1984) Language, Thought and Other Biological Categories, Mit Press. For a criticism of Millikan's view of language see G. Origgi, D. Sperber (2000) "Evolution, Communication and the Proper Function of Language", in P. Carruthers, A. Chamberlain (eds.) Evolution and the Human Mind, Cambridge University Press.

27 Cf. T. Burge (1993) "Content Preservation" Philosophical Review, 101, pp. 457-88. C. A. Bezuindehout (1978) "Is verbal Com " Journal of Philosophy, 107, pp. 261-288.

Words, Harvard University Press

1986/1995) Relevance: Communication and Cognition

"' For an insightful analysis of the role of the Gricean framework in understanding trust, see J.

Adler (1994) "Testimony Trusting, Knowing", Journal of Philosophy, 94 pp 264-275;

R. Moran (1999) "Believing the Speaker", unpublished manuscript.

pp. 583-632.

For the notion of "common ground" see D. Lewis (1983) "Languages and Language" Philosophical Papers, vol. 1, Oxford University Press, pp. 163-188. The notion of "mutual cogniive environment is developed in Sperber \& Wilson (1986/95) Cit.

Cf. P. Bloom (2000) How Children Learn the Meanings of Words, MIT Press; G. Origgi,

D. Sperber cit.

* I am grateful to Dan Sperber for his helpful comments and detailed suggestions from the earliest formulation of this paper. Much of this work is indebted to his ideas on communication. A previous version of this paper has been presented at the workshop. Concept of Authority held

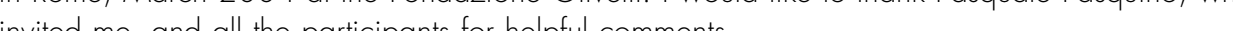

\section{Author's Biography}

Gloria Origgi is a philosopher at the Centre Nationale de la Recherche Scientifique in Paris. Her research interests are philosophy of mind, epistemology and cognitive science as applied to new technologies. She is the author of Introduzione a Quine (2000). She has co-authored articles 